KENOSIS : JURNAL KAJIAN TEOLOGI

ISSN 2460-6901(Print), 2656-4483 (Online)

https://e-journal.iaknambon.ac.id/index.php/KNS

DOI: $10.37196 /$ kenosis.v7i2.226

\title{
KONSTRUKSI KERANGKA KONSEPTUAL PERANAN ROH KUDUS DALAM PAK MENGGUNAKAN TAKSONOMI BLOOM YANG DIPERBARUI
}

\section{Hanny Setiawan dan Yonatan Alex Arifianto}

\author{
Sekolah Tinggi Teologi Berita Hidup Solo \\ Jl. Raya Solo - Kalioso KM. 7 Selorejo, Solerejo, Wonorejo, \\ Kec. Gondangrejo, Kabupaten Karanganyar, Jawa Tengah 57188 \\ hannysetiawan@gmail.com \\ Sekolah Tinggi Teologi Sangkakala \\ Jl. Raya Salatiga, Pijil, Kopeng, Kec. Getasan, Kabupaten Semarang, \\ Jawa Tengah 50774 \\ arifianto.alex@sttsangkakala.ac.id
}

\begin{abstract}
A learning process is aimed toward outcomes. The desired outcomes are the initial point to construct the proper conceptual framework to describe theoretical foundation of a research. Spirituality and spiritual behaviour are two outcomes that Christian Education thinkers agreed upon from Old Testament to now. The meeting between Greeco-Roman and Jewish culture had somewhat changed the trajectory of how Christian Education develops. The Greek cognitive-based learning has influenced the initial Christian Education which is Jewish learning system. This article attempts to describe how spirituality, spiritual behaviour, and spiritual knowledge serve as the ultimate outcomes of Christian Educatian. The description will fit with the role of Holy Spirit in the overall process of Christian Education in any given scopes. As a result, this article will construct a conceptual framework that can be utilized further to design a biblical curriculum that is not merely cognitively measureable, but also to provide an intentional outcomes of spirituality and spiritual behaviour. The revised Bloom's taxonomy will be used to bridge the both worlds : the cognitive, and non-cognitive. In conclusion, this article shows that the supernatural work of Holy Spirit is not against the natural work of Holy Spirit through teacher and student relationship in Christian Education, but both work together.
\end{abstract}

Keyword: Holy Spirit, Christian religious education, Bloom's taxonomy, spirituality. 


\begin{abstract}
Abstrak
Proses pembelajaran ditujukan untuk mencapai suatu hasil. Hasil yang diinginkan merupakan titik awal untuk membangun kerangka konseptual yang tepat untuk mendeskripsikan landasan teoritis sebuah penelitian. Spiritualitas dan perilaku spiritual adalah dua hasil yang disepakati oleh para pemikir pendidikan Kristen dari zaman Perjanjian Lama hingga sekarang. Pertemuan antara budaya YunaniRomawi dan Yahudi telah mengubah lintasan (trajectory) Pendidikan Kristen berkembang. Pembelajaran berbasis kognitif Yunani telah mempengaruhi sistem pembelajaran Yahudi. Artikel ini mencoba untuk menjelaskan bagaimana spiritualitas, perilaku spiritual, dan pengetahuan spiritual berfungsi sebagai hasil akhir dari Pendidikan Kristen. Hasil akhir tersebut dapat menggambarkan secara konseptual peran Roh Kudus dalam keseluruhan proses Pendidikan Kristen dalam lingkup apa pun. Sebagai hasil akhir, artikel ini akan menyajikan bangunan kerangka konseptual yang dapat digunakan lebih jauh untuk merancang kurikulum alkitabiah yang tidak hanya dapat diukur secara kognitif, tetapi juga untuk memberikan hasil yang disengaja dari spiritualitas dan perilaku spiritual. Taksonomi Bloom yang telah direvisi akan digunakan untuk menjembatani kedua dunia: kognitif dan non-kognitif. Artikel ini menunjukkan bahwa pekerjaan supernatural Roh Kudus tidak bertentangan dengan pekerjaan alami Roh Kudus melalui hubungan guru dan murid dalam pendidikan Kristen, tetapi keduanya bekerja sama.
\end{abstract}

Kata Kunci: Roh Kudus, pendidikan agama Kristen, taksonomi Bloom, spiritualitas

\title{
PENDAHULUAN
}

Kualitas proses pembelajaran terlihat dari hasil akhir atau final outcomes yang dicapai. Kurikulum disusun berdasarkan apa yang diajarkan (what to teach) dan bagaimana kita mengajarkannya (how to teach). Apa yang diajarkan (content) dalam suatu kurikulum sangat bergantung dengan hasil akhir yang hendak dicapai (outcomes). Hal ini berlaku secara universal, baik dalam pendidikan umum ataupun pendidikan agama Kristen. Meskipun demikian, Pendidikan Agama Kristen (PAK) memiliki keunikan yang menjadi faktor pembeda utama, ${ }^{1}$ dengan pendidikan secara umum yaitu, peran Roh Kudus sebagai guru utama dalam proses pembelajaran PAK. Hasil akhir berupa kebenaran sejati atau hanya kebenaran humanis ditentukan dari ada atau tidaknya kehadiran Roh Kudus dalam proses pembelajaran PAK. ${ }^{2}$

Metanarasi Alkitab dari Kejadian sampai Wahyu memperlihatkan bahwa Roh Kudus hadir sejak awal dunia, sampai akhir dunia. Kejadian 1:2 dan Wahyu 22:17 memperlihatkan sekaligus membuktikan bahwa Roh Kudus adalah salah satu Pribadi 
dari Trinitas yang berperan untuk melahirkan, mengajar, dan mendewasakan peradaban manusia. Dengan kata lain, Roh Kudus selalu ada sejak awal dunia sebagai pengajar, bukan hanya ketika Roh Kudus dikirim kepada Gereja-Nya di hari Pentakosta (Kis. 2). Milliar J. Erickson menyatakan bahwa hanya melalui Roh Kudus kita dapat mengalami perjumpaan pribadi dengan Allah, ${ }^{3}$ dan juga menjadi titik awal Trinitas menjadi personal dalam kehidupan orang percaya, "the Holy Spirit is the point at which the Trinity becomes personal to believers." 4

Kualitas output dari PAK yang berupa Sumber Daya Manusia (SDM) yang unggul tidak dapat dilepaskan dari peran Roh Kudus. ${ }^{5}$ Yang menjadi jurang penelitian (research gap) yang dikaji dalam artikel ini adalah tidak adanya alat ukur yang jelas yang dipakai untuk mengukur tingkat peran Roh Kudus dalam PAK. Menggunakan rumusan Hardi Budiyana sebagai apa yang disebut sasaran akhir PAK, ${ }^{6}$ artikel ini mengategorikan sasaran akhir PAK dari PAK di semua lingkup pembelajaran (gereja, sekolah, rumah) adalah spiritualitas, moralitas, dan kapasitas.

Moralitas yang juga disebut budi pekerti atau karakter, ${ }^{7}$ serta kemampuan kognitif adalah dua hal yang menjadi sorotan dalam pendidikan baik umum maupun PAK. Tetapi, secara khusus PAK memperhatikan spiritualitas sebagai sasaran untuk dicapai. Spiritualitas yang bersifat non-kognitif inilah yang memerlukan tolok ukur yang lebih nyata. Zohar dan Marshal membedakan kecerdasan spiritual dengan kecerdasan kognitif. Kecerdasan spiritual dikatakan memberikan makna, kontekstual, dan bersifat transformatif. ${ }^{8}$ Haryo Basuki lebih jauh menyimpulkan bahwa kecerdasan spiritual memengaruhi prestasi belajar kognitif. ${ }^{9}$

Artikel ini berargumen bahwa peran antara Roh Kudus dalam membawa perubahan terhadap PAK bisa dikategorikan dalam kecerdasan spiritual ${ }^{10}$; Perilaku yang dilahirkan dari Roh Kudus disebut "buah Roh.” Pemikiran Roy B. Zuck yang mengatakan "Pendiaman (indwelling) oleh Roh Kudus dalam diri orang percaya itu merupakan dasar untuk pengajaran Allah (it is the basis for His teaching)" menjadi dasar kebenaran dalam PAK yang menghubungkan antara Roh Kudus dan spiritualitas. Rasul Yohanes menguatkan pemikiran ini dengan mengatakan bahwa di dalam diri kita ada pengurapan yang akan mengajar kita (1Yoh. 2:27). Kata Yunani

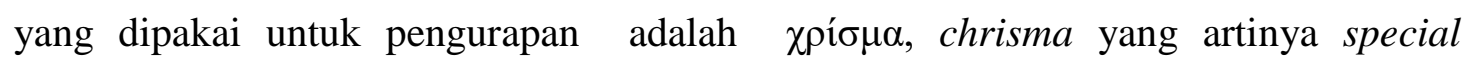
endowment of Holy Spirit. ${ }^{11}$ Kata endowment (kapasitas, kekuatan, dan kemampuan 
yang diberikan Roh Kudus) sangat tepat menggambarkan indwelling (pendiaman) yang dikatakan Zuck. Bisa disimpulkan bahwa dalam PAK spiritualitas bersifat hubungan pribadi para pelaku (variabel) dalam sistem pembelajaran dengan Roh Kudus. Artinya, setiap orang yang terlibat dalam sistem dari guru, murid, orang tua, pengurus sekolah bahkan, pemilik segala yang harus memiliki hubungan pribadi dengan Roh Kudus dalam satu lingkup pembelajaran. Guru dan murid adalah orang yang langsung terlibat, tetapi keberadaan orang tua (wali), pengurus (manajemen), dan pemilik sekolah yang menentukan kebijakan sangat strategis dalam menentukan hasil akhir pembelajaran.

Spiritualitas, moralitas, dan kapasitas adalah tiga hasil akhir yang ditawarkan dalam penelitian ini untuk membangun kerangka konseptual dalam PAK dalam semua lingkup pembelajaran. Kerangka konseptual adalah sebuah diagram yang dipakai untuk menggambarkan sebuah kerangka teoritis. ${ }^{12}$ Untuk mengembangkan kerangka konseptual, penelitian menggunakan metakognisi yang diperkenalkan oleh (siapa) yang dikenal dengan nama Taksonomi Bloom, yang kemudian diperbarui dan juga diperkuat oleh Taksonomi Marzano sebagai kerangka teoritis. Metakognisi yaitu kesadaran akan kognisi atau berpikir itu sendiri sudah ada sejak usia dini. ${ }^{13}$ Artinya, secara teoritis dapat dipergunakan untuk semua lapis usia, baik secara pedagogi maupun andragogi. ${ }^{14}$ Sebagai kesimpulan, artikel ini akan memberikan diagram kerangka konseptual PAK beserta keterangannya untuk menyajikan hasil penelitian dan pembahasan. Berdasarkan kerangka konseptual ini dapat dikembangkan kurikulum ataupun penelitian-penelitian lebih lanjut bagaimana sistem PAK dapat dikembangkan dan diimplementasikan.

\section{METODE PENELITIAN}

Metode kualitatif untuk mendapatkan makna ${ }^{15}$ digunakan bersaman dengan studi pustaka terutama dari buku dan jurnal-jurnal terbaru untuk pencarian data, dan menemukan hubungan timbal-balik antara variabel-variabel yang ada. Penelitian dilakukan di tataran analitis dan bersifat perspective emic, artinya data didasarkan fakta-fakta konseptual, atau fakta teoritis. ${ }^{16}$ Dua variabel primer dipergunakan untuk diteliti, yaitu analisa biblis narasi Roh Kudus dalam Alkitab, dan Taksonomi Bloom yang diperbarui. Kesimpulan antara kedua variabel dilakukan dengan memunculkan 
variabel kunci ke-3 yaitu metakognisi. Variabel Pemetaan antar metakognisi dan pneumatologi adalah hasil analisis yang menjadi landasan teoritis untuk mengembangkan kerangka konseptual.

\section{HASIL DAN PEMBAHASAN}

Kehadiran Roh Kudus di dalam Alkitab dimulai dari Kejadian sampai Wahyu. Dalam kitab Kejadian 1:2 dikatakan, "Bumi belum berbentuk dan kosong; gelap gulita menutupi samudera raya, dan Roh Allah melayang-layang di atas permukaan air." Kata melayang-layang yang dalam versi NIV dan Darby, ${ }^{17}$ digunakan frasa "hovering over", atau "moving over" (NASB), ${ }^{18}$ dalam Bahasa Indonesia secara literal dipakai kata "mengeram." Sedangkan kata Ibrani רָח (rachaph) dapat diartikan incubate, brood, dan hatch. Dari penjelasan sebelumnya, dapat disimpulkan bahwa Roh Kudus hadir sejak awal penciptaan untuk mengerami dan menginkubasi bumi yang dalam keadaan kosong dan gelap. Dalam Wahyu 22:17 dikatakan, "Roh dan pengantin perempuan itu berkata: "Marilah!" Dan barangsiapa yang mendengarnya, hendaklah ia berkata: "Marilah!" Dan barangsiapa yang haus, hendaklah ia datang, dan barangsiapa yang mau, hendaklah ia mengambil air kehidupan dengan cumacuma!" Roh dan pengantin perempuan yang merujuk kepada Gereja Tuhan (Mrk 2:19; 2Kor 11:12;Ef. 5:32). Dalam TPT (Passion Translation) konsep ... diuraian dengan dengan frasa, "Come," says the Holy Spirit and the Bride in divine duet. Ada duet Ilahi antara Roh Kudus dan Gereja-Nya untuk menyuarakan suara profetis, "Marilah". Hal ini memperlihatkan sampai kesempurnaan Gereja-Nya, Roh Kudus tetap mendampingi.

Roh Kudus yang melahirkan (Yoh. 3:8), mengerami (Kej. 1:2), sampai pada akhirnya Dia juga yang mendampingi Gereja-Nya (Why. 22:17), adalah Roh yang sama yang diutus untuk menolong, mengajar, menjadi "orang tua" supaya tidak menjadi yatim piatu (Yoh. 14:16), menghibur, dan menginsafkan akan dosa, kebenaran, dan penghakiman (Yoh. 16:6-7), memimpin kepada kebenaran, memberitahukan hal yang akan datang, dan semua yang Yesus katakan (Yoh. 16:1316).

Perlu menjadi catatan khusus, sebelum Pentakosta (lima puluh hari setelah kebangkitan Yesus), ketika murid-murid yang berjumlah 120 ada di loteng Yerusalem 
menunggu Roh Kudus (Luk. 24:29, Kis 1:4-5) sebenarnya para murid sudah "menerima Roh Kudus" di hari pertama kebangkitan Yesus. Hari pertama Kebangkitan Yesus mungkin tidak begitu sering dihubungkan dengan Roh Kudus, tapi sebenarnya para murid yang ketakutan di pintu-pintu terkunci sudah "menerima Roh Kudus" di hari pertama Kebangkitan Yesus. seperti yang dinyatakan dalam kitab Yohanes bahwa Yesus menghembusi mereka dengan Roh Kudus. Ketika hari sudah malam pada hari pertama minggu itu berkumpullah murid-murid Yesus di suatu tempat dengan pintu-pintu yang terkunci karena mereka takut kepada orang-orang Yahudi. Pada waktu itu datanglah Yesus dan berdiri di tengah-tengah mereka dan berkata: "Damai sejahtera bagi kamu!"... Dan sesudah berkata demikian, Ia mengembusi mereka dan berkata: "Terimalah Roh Kudus..." (Yoh. 20:19, 22). Dari pernyataan rasul Yohanes mengungkapkan kehadiran Roh Kudus sangat membawa perubahan bagi murid-murid Yesus. Namun kesulitan teologis muncul bagaimana murid-murid yang sudah menerima Roh Kudus tapi diminta untuk menunggu Roh Kudus? Jonathan Sheet seorang pendeta dari Gereja Methodis, sekaligus doktor teologi dari Princeton Theological Seminary dan Francisco Theological Seminary mendapatkan pengertian ini dengan sangat jelas. Sheet membedakan antara "menerima" (come into), dan "turun" (come upon). Dalam bukunya, The River Runs, Sheet mengatakan,

"The key concept here is that Jesus wanted the Holy Spirit to come UPON the disciples to empower them. This is different from the Holy Spirit coming INTO us to seal us for our salvation because He is also our "deposit" for salvation (II Cor. 1:22, 5:5; Ep. 1:13-14; 4:30) On the Day of Pentecost, the Holy Spirit came upon the disciples to empower them. He was already in them but Jesus wanted the Holy Spirit to come upon them so that they would receive power. It is this power that enabled them, and will enable us, to fulfil what Jesus said. ${ }^{19}$

\section{Roh Kudus dan Ekklesia, Misi, dan Spiritualitas}

Roh Kudus sebagai Pribadi ketiga dari Trinitas bekerja secara kosmis (ekklesia), global (misi), sekaligus personal (spiritualitas). Yang pertama, secara kosmis, pernyataan sentral misi Yesus Kristus untuk membangun ekklesia (Mat. 16:18) adalah dasar yang paling kuat bahwa Roh Kudus memiliki tujuan utama 
membangun ekklesia di bumi. Itulah hati Yesus, dan Roh Kudus tidak akan memberitakan, dan melakukan apapun yang bukan menjadi hati dan agenda Yesus (Yoh. 16:14). Seperti yang sudah disebut dalam Wahyu 22:17, "the spirit and the bride" sebagai sebuah gambaran eskatologis, bahwa Roh Kudus dan sang mempelai yang adalah Gerejanya, atau Ekklesia tidak bisa dipisahkan, selalu bergerak bersama. Roh Kudus tidak hanya bekerja secara pribadi, tapi juga secara korporat. ${ }^{20}$ Doa Yesus di Yoh 17 adalah "kerinduan ekklesiologis" yang bersifat kosmis. Hal ini bisa dinyatakan Paulus dalam Efesus 1:10, "sebagai persiapan kegenapan waktu untuk mempersatukan di dalam Kristus sebagai Kepala segala sesuatu, baik yang di surga maupun yang di bumi." Sebagai sebuah kesatuan (oneness) yang bersifat mistis dan supranatural. Tanpa Roh Kudus, kesatuan yang digambarkan tidak akan bisa tercapai. Artinya, ekklesia tidak akan terbentuk.

Yang kedua, peran Roh Kudus dalam misi sangat terlihat di dalam laporan ilmiah Lukas di Kisah Para Rasul. Laporan ilmiah, yang diartikan oleh Evan adalah data yang sudah diinvestigasi dan diteliti, ditulis secara teratur, sehingga memberikan informasi (pengetahuan) yang benar. ${ }^{21}$ Jadi, ketika Kisah Para Rasul 1:8 memperlihatkan lokasi Yerusalem, Yudea, Samaria, sampai ke ujung bumi, hal tersebut bukan sebuah nubuatan yang akan terjadi, tetapi sebuah laporan penelitian yang akurat. Hal ini memberikan bukti kuat bahwa karya Roh Kudus dalam misi adalah hal yang teruji dan akurat. Artinya, peran Roh Kudus dalam misi bukan sebuah narasi yang abstrak yang bersifat normatif.

Kisah Filipus dengan sida-sida Ethiopia memperlihatkan bagaimana Filipus “dibawa lari Roh Kudus" menuju Asdod (Kis. 8:39). ${ }^{22}$ Kata yang dipakai untuk "melarikan" adalah $\dot{\alpha} \rho \pi \alpha ́ \zeta \omega$, harpazō yang artinya ditangkap, diambil dengan paksa, ataupun dicabut. Ini memperlihatkan contoh bagaimana Roh Kudus memimpin perjalanan misi itu sendiri secara personal. Kisah Para Rasul 1:8 disebut sebagai master plan misi, ${ }^{23}$ yang artinya Roh Kudus memiliki strategi, organisasi, dan implementasi bagaimana Injil dikabarkan dari Yerusalem sampai ke ujung bumi. Tidak ada yang yang acak, semua ada dalam rencana-Nya dan Roh Kudus yang memimpin.

Yang ketiga, hubungan personal antara Roh Kudus dengan kehidupan seseorang sejak kelahiran baru dalam artikel ini didefiniskan dengan spiritualitas. I 
Korintus 12:7 menyatakan, "Tetapi kepada tiap-tiap orang dikaruniakan penyataan Roh untuk kepentingan bersama." Hubungan ini oleh Yesus diajarkan seperti pokok Anggur dan ranting. Tanpa melekat kepada pokok, ranting tidak akan berbuah (Yoh. 15:1-7). Kemelekatan dan hubungan yang dekat ini akan melahirkan perilaku dan perbuatan yang sesuai. Inilah yang disebut buah Roh oleh Paulus (Gal. 5). Jadi, perilaku spiritual yang benar adalah hasil dari Roh Kudus yang berdiam (indwelling) di dalam orang tersebut. Hardi Budiyana mengutip Roy B. Zuck mengatakan, Pendiaman (indwelling) oleh Roh Kudus dalam diri orang percaya itu merupakan dasar untuk pengajaran Allah (it is the basis for His teaching)." Roy menghubungkan ayat ke-20 dan ayat ke-27 dari I Yohanes 1. Hal tersebut karena ada Roh Kudus di dalam diri orang percaya maka orang percaya bertumbuh dalam proses pembelajaran. Tetapi kamu telah beroleh pengurapan dari Yang Kudus. ${ }^{24}$

Roh kudus dalam diri orang percaya adalah kunci sukses pembelajaran, baik guru dan murid maupun murid yang lain (dalam kelas) masing-masing adalah subjek sekaligus objek pembelajaran. Subjek karena ada Roh Kudus di dalamnya, sekaligus objek karena menerima pembelajaran. Konsep ini sama dengan Yohanes 15:7, "Jikalau kamu tinggal di dalam Aku dan firman-Ku tinggal di dalam kamu, mintalah apa saja yang kamu kehendaki, dan kamu akan menerimanya." Robert Pazmino menyatakan peran penting Roh Kudus dengan lebih tegas, "Pencarian manusia akan kebenaran dalam pendidikan harus dilihat dalam hubungannya dengan Allah sebagai sumber semua kebenaran. Roh Kudus menerangi pikiran manusia sehingga mereka bisa membedakan kebenaran di dalam penyataan khusus dan penyataan umum."25

Tanpa spiritualitas, perbuatan yang benar hanya akan menjadi sebuah perilaku lahiriah (bergerak secara psikologis), bukan perilaku spiritualitas. Kitab 2 Timotius 3:5 memperlihatkan, "Secara lahiriah mereka menjalankan ibadah mereka, tetapi pada hakikatnya mereka memungkiri kekuatannya. Jauhilah mereka itu!” Dalam konteks ibadah, tanpa spiritualitas berarti adalah tanpa iman dan tanpa hubungan disebut oleh Yesus sebagai orang munafik (Mat. 6:2,5). Kata munafik ini berasal dari kata Yunani

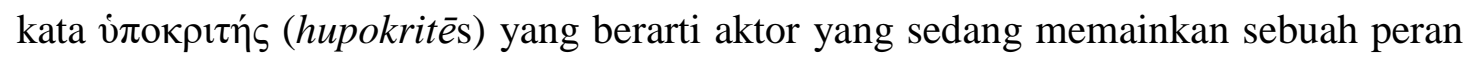
dalam drama. Perilaku lahiriah dalam beragama inilah yang biasa disebut perilaku agamawi. Di luar agama, perilaku lahiriah inilah yang disebut perbuatan (Éprov,

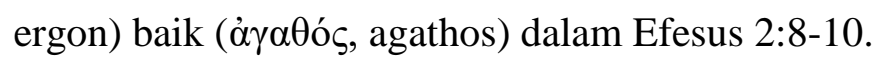


Perbuatan tidak menyelamatkan, tetapi di dalam Yesus kita dipersiapkan untuk segala perbuatan baik. Efesus 2:10. "Karena kita ini buatan Allah, diciptakan dalam Kristus Yesus untuk melakukan pekerjaan baik, yang dipersiapkan Allah sebelumnya. Ia mau, supaya kita hidup di dalamnya." Sebab sejatinya pengiringan akan Yesus membawa keyakinan yang teguh untuk terus hidup dalam percaya kepada Tuhan. ${ }^{26}$ Sebab kepercayaan kepada Tuhan atau beriman memiliki hubungan, dan memiliki spiritualitas adalah titik awalnya, bukan perbuatan baik. Bagaimana dengan perbuatan baik tanpa spiritualitas, tanpa iman? Perbuatan baik yang dilandasi kasih kepada sesama tanpa kasih kepada Tuhan tidak akan mengubah substansi dari perbuatan baik tersebut. Perbuatan seperti ini dikategorikan moralitas. Jadi, spiritualitas akan melahirkan moralitas, tapi moralitas belum tentu didasarkan oleh spiritualitas.

Dalam perkembangan di dunia pendidikan, ukuran dalam spiritualitas disebut dengan kecerdasan spiritual (spiritual intelligence). Kecerdasan spiritual muncul sebagai suatu upaya pembanding bagi kecerdasan kognitif (intellectual intelligence) dan kecerdasan emotional (emotional intelligence). Zohar dan Marshall yang pertama kali menggunakan istlah kecerdasan spiritual menggambarkannya sebagai kecerdasan diri yang mendalam yang mampu menjawab pertanyaan-pertanyaan mendasar, sehingga dapat memecahkan masalah makna dan nilai yang mampu menempatkan tindakan (perilaku) dalam konteks yang lebih luas. ${ }^{27}$ Dari definisi Zohar dan Marshall bisa dikatakan kecerdasan spiritual adalah sebuah worldview (wawasan dunia) yang oleh David K. Naugle dipahami secara teologis, "sebagai sistem theistik yang memperlihatkan koherensi rasional dari pewahyuan Alkitab"28

Jadi, spiritualitas yang mengacu kepada kecerdasan spiritual yang adalah karya Roh Kudus adalah titik temu antara rasionalitas dan pewahyuan Alkitab yang menjadi sebuah wawasan dunia (worldview) yang benar adalah outcome yang diharapkan PAK dalam mengaktualisasi segala proses pembelajaran. Bukti adanya kecerdasan yang dinyatakan oleh Roh Kudus kepada manusia melalui karunia dari Roh Kudus yang dinyatakan oleh rasul Paulus di jemaat Korintus. Selain spiritualitas dan moralitas (perilaku),ada domain ketiga yang disebut pengetahuan. Dalam Alkitab, ada 3 taksonomi pengetahuan yang terdapat dalam Kolose 1:9, yaitu pengetahuan

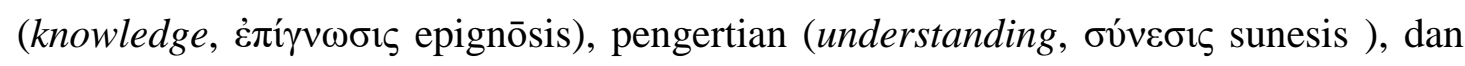
hikmat (wisdom, бọía sophia). Dalam filsafat, taksonomi pengetahuan disebut 
epistemologi yang oleh Khoe Yang Tung disebutkan berkaitan dengan pertanyaan, "What is the nature of knowledge". ${ }^{29}$ Pengetahuan inilah yang dalam teologi sistematika menjadi objek untuk diformulasikan, dikategorikan, dan dideskripsikan. Komponen-komponen kognitif, afektif, dan psikomotorik, ${ }^{30}$ dapat dipakai untuk mengukur (assessment) transfer pengetahuan yang sudah terjadi dalam proses pembelajaran.

Simon Chan dalam bukunya berjudul Spiritual Theology membedakan dua jenis teologi menjadi teologi spiritualitas yang berfokus kepada kerohanian dan teologi sistematika yang secara kognitif menerangkan apa yang dialami (implikasi praktis). Subjek teologi rohani berkaitan dengan perkembangan kehidupan rohani. Berkaitan dengan metodenya, teologi rohani membangun penemuan teologi sistematis dan mencari implikasi praktisnya. Dengan kata lain, teologi sistematis memusatkan perhatian pada konsep-konsep dan formulasi rasional dari pengalaman Kristen, sedangkan kerohanian memusatkan perhatian pada pengalaman di balik formulasi tersebut. $^{31}$

Untuk domain pengetahuan, saya menawarkan kata kunci kapasitas untuk menjadi hasil akhir yang ketiga setelah spiritualitas dan moralitas dalam Pendidikan Agama Kristen. Kapasitas menampung pengetahuan secara intelektual dan kognitif. Kapasitas lebih nyata dan lebih mudah diukur karena bersifat nyata, dibandingkan dengan spiritualitas dan moralitas. Dengan tiga outcomes utama ini, maka PAK tidak lagi hanya sasaran akhir kepada hal-hal yang bersifat "rohani" dan melupakan pengetahuan sebagai bagian dari sebuah pertumbuhan secara utuh. Atau kebalikannya, hanya berfokus kepada kognitif dan mengembangkan kapasitas, tetapi tidak mengindahkan spiritualitas dan moralitas. Perumusan ini sejalan dengan Budiyana yang menuliskan sasaran akhir PAK dirumuskan sebagai berikut, "Peran Pendidikan Agama Kristen, bukan saja menciptakan proses pembelajaran terhadap pendidikan bagi anak didik atau jemaat dalam hal pengetahuan (kognitif), sikap (afektif) dan keterampilan (psikomotorik). Pendidikan Agama Kristen harus juga memiliki peran dalam memperbaharui orang berdosa yaitu mempersatukan kembali persekutuan antara manusia dengan Allah yang telah putus karena dosa. Pendidikan Agama Kristen harus mempertemukan kembali Pribadi seseorang kepada Kristus... 
Oleh karena itu seseorang yang sudah percaya Yesus harus diperbaharui karakternya dari hari ke sehari. ${ }^{32}$

Dengan menggunakan spiritualitas, moralitas, dan kapasitas sebagai hasil akhir PAK dalam semua ruang lingkup, maka sebuah kerangka konseptual dapat dikembangkan secara objektif dan terukur. Terobosan "tiga dimensi outcome" ini adalah penemuan yang dapat dipergunakan untuk memecah kebuntuan antara outcome yang bersifat kognitif yang terlihat dan non-kognitif yang tidak terlihat.

\section{Kerangka Konseptual dan Taksonomi Bloom Yang Diperbaharui}

Dickson Adom dan Emad Kamil Hussein mengutip Camo mengatakan bahwa kerangka konseptual adalah struktur dalam sebuah penelitian dan berhubungan dengan konsep, riset empiris, dan teori-teori penting untuk membuat sistematis pengetahuan yang didukung peneliti. ${ }^{33}$ Dari kerangka teoritis (theoretical framework), sebuah kerangka konseptual (conceptual framework) dibangun. Artikel ini berusaha untuk mengkonstruksi sebuah kerangka konseptual yang dapat dipakai untuk menjadi pijakan baru dalam PAK di semua ruang lingkup implementasi baik keluarga, gereja, maupun sekolah formal, atau nonformal di semua jenjang umur. Tulisan ini mencoba membangun sebuah blueprint PAK yang dapat dipergunakan untuk mendesain kurikulum yang dibutuhkan. Kerangka konseptual berbentuk diagram yang lengkap seperti denah sebuah rumah atau bangunan yang digunakan untuk membangun. Adom dan Hussein memberikan gambaran sebuah kerangka konsep yang bagus adalah:

"Conceptual frameworks are generative frameworks that reflects the thinking of the entire research process. Mostly, diagrams are created to clearly define the constructs or variables of the research topic and their relationships are shown by the use of arrows.. a good conceptual framework must also be expressed in writing for it to be understood clearly. This means that after a researcher has craftily produced a diagrammatic representation of the main variables of the study, s/he has to explain the relations among them and how their complementation helps in answering the major research problem defined. ${ }^{34}$ 
Taksonomi Bloom yang sudah direvisi akan digunakan untuk menjadi alat bantu membangun kerangka konseptual di artikel ini. Taksonomi Bloom disebutkan sebagai taksonomi tujuan pendidikan (The Taxonomoy of Educational Objectives). Secara definisi, David R. Krathwohl menyatakan,'The Taxonomy Of Educational Objectives is a framework for classifying statements of what we expect or intend students to learn as a result of instruction." 35 Intinya, taksonomi Bloom adalah sebuah kerangka kerja untuk mengklasifikasikan proses-proses pembelajaran yang harus dialami untuk mencapai hasil akhir yang diinginkan. Dalam konteks artikel ini, untuk mencapai spiritualitas, moralitas, dan kapasitas, diperlukan tangga-tangga proses yang menjadi tujuan pembelajaran (learning objectives) menuju yang diinginkan.

Taksonomi Bloom yang diperbarui memiliki perbedaan dengan yang orisinil. Versi orisinil, hanya satu domain yaitu domain kognitif, yang mencakup pengetahuan (knowledge), pemahaman (comprehension), aplikasi (application), analisis (analysis), sintesis (synthesis), dan evaluasi (evaluation). Sementara Taksonomi Bloom yang sudah direvisi Anderson dan Krathwohl yang mencakup dua domain yaitu domain kognitif dan pengetahuan. Domain kognitif mencakup tahapan mengingat (remember), memahami (understand), mengaplikasikan (apply), menganalisis (analyze), mengevaluasi (evaluate), dan mencipta (create). Domain pengetahuan ada pengetahuan faktual, prosedual, konseptual, dan metakognisi. Domain yang keempat yaitu metakognisi adalah sesuatu yang baru, bukan hanya kategori tapi substansinya dalam taksonomi bloom. Krathwohl mengatakan, "Metacognitive Knowldge involves knowledge about cognition in general as well as awareness of and knowledge about one's own cognition" 36 
Gambar berikut memperlihatkan kerangka konseptual Taksonomi Bloom yang sudah direvisi. ${ }^{37}$

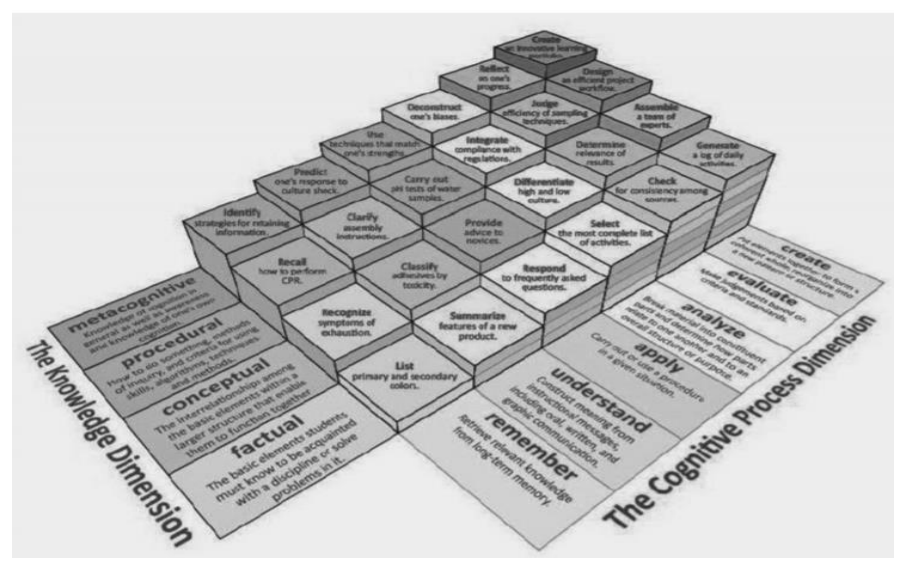

Gambar 1. (kerangka konseptual Taksonomi Bloom yang sudah direvisi )

\section{Metakognisi}

Dalam Taksonomi Bloom yang terbaru, dimensi pengetahuan metakognisi adalah level yang tertinggi. Metakognisi ada di tataran HOTS (High Order Thinking Skill) dan dapat didefinisikan sebagai "thinking of thinking" atau berpikir tentang berpikir, sehingga bisa "learn to learn" (belajar untuk belajar). Zainal Fanani menerangkan, "Higher order thinking skills (HOTS) atau keterampilan berpikir tingkat tinggi merupakan bagian dari taksonomi Bloom hasil revisi yang berupa kata kerja operasional yang terdiri dari analyze $(\mathrm{C} 4)$, evaluate $(\mathrm{C} 5)$ dan create $(\mathrm{C} 6){ }^{38}$

Selain Bloom, Marzano dalam taksonomi yang dikembangkan juga menempatkan sistem metakognisi sebagai bagian terpenting yang membentuk kepribadian (Self-System) ${ }^{39}$ Marzano menyebutkan metakognisi sebagai executive control (kontrol untuk bertindak). Dengan kata lain, metakognisi adalah kontrol untuk perilaku. Perubahan dalam metakognisi akan menjadi perubahan perilaku. Sebab itu, perubahan dalam metakognisi inilah yang menentukan kecerdasan spiritual, yang berarti adalah wilayah dimana Roh Kudus bekerja. Indarini, Sadono, dan Onate merujuk kepada Flavell (1979) pencetus pertama konsep metakognisi mengatakan bahwa metakognisi mencakup tiga hal, yaitu pengetahuan tentang strategi (strategy variables), pengetahuan tentang tugas kognitif (task variables), dan pengetahuan diri (person variables). ${ }^{40}$ Ketiga pengetahuan metakognisi ini selaras dengan tiga karya Roh Kudus (pneumatologi) yang sudah dibahas di atas, yaitu: Roh Kudus dan 
Spiritualitas, Roh Kudus dan Misi, dan Roh Kudus dan Ekklesia. Tabel 1.1 Memperlihatkan pemetaan antara metakognisi dan pneumatologi yang bisa menjadi dasar untuk mengembangkan penelitian lebih lanjut.

\section{Mapping Metakognisi dan Pneumatologi}

\begin{tabular}{|l|l|}
\hline \multicolumn{1}{|c|}{ Metakognisi } & \multicolumn{1}{c|}{ Pneumatologi } \\
\hline Pengetahuan Pribadi (Personal Variables) & Roh Kudus dan Spiritualitas \\
\hline Pengetahuan Tugas (Task Variables) & Roh Kudus dan Misi \\
\hline Pengetahuan Strategi (Strategic Variables) & Roh Kudus dan Ekklesia \\
\hline
\end{tabular}

\section{Tabel Mapping Metakognisi dan Pneumatologi}

\section{Kerangka Konseptual PAK 1.0}

Dalam PAK dikenal komponen-komponen pembelajaran. Hardi Budiyana menyebutkan ada 6 komponen dasar PAK yaitu, pendidik, murid, dan kurikulum (materi), tujuan, metode, dan evaluasi. ${ }^{41}$ Hal itu merupakan komponen yang mendukung dalam kerangka konseptual PAK 1.0. seperti yang diutarakan oleh Cepi Riyana, menawarkan kerangka konseptual pembelajaran seperti yang terlihat di gambar $1^{42}$

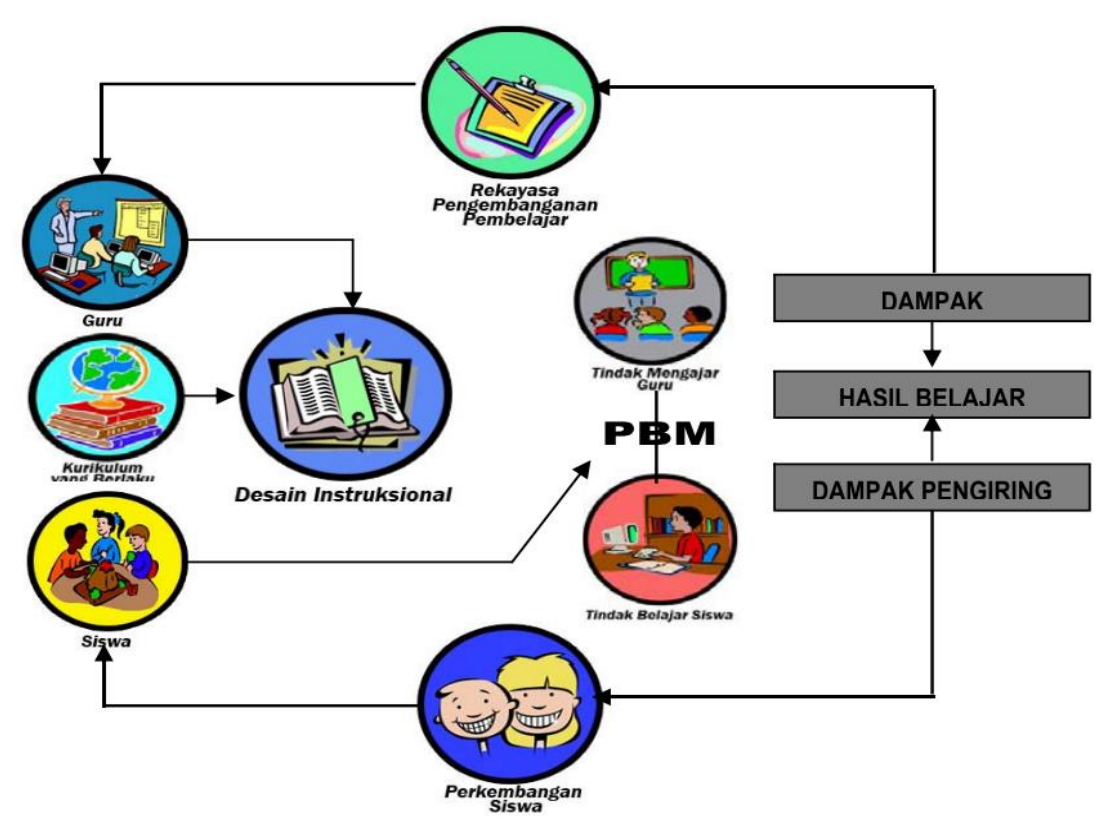

Gambar 2. (kerangka konseptual pembelajaran) 
Apa yang diusulkan Budiyana dan Riyana tidak berbeda banyak memperlihatkan sebuah kerangka konseptual pendidikan yang umum. Keterlibatan Roh Kudus tidak dimasukkan secara sengaja (intentional) dalam seluruh proses pembelajaran. Hal ini bertentangan dengan bukti-bukti analisis biblis dan juga metakognisi bahwa kecerdasan spiritual tidak bisa dipisahkan dari moralitas dan kapasitas.

Proses pengembangan kurikulum dimulai dari dasar, konstruksi, implementasi, sampai kepada evaluasi haruslah sebuah koherensi. ${ }^{43}$ Hasil akhir yang diharapkan (dalam hal ini adalah spiritualitas) harus ada sudah ada sejak dari dasar (fondasi) pembentukan. Sebab jika tidak ada pondasi maka tidak bisa mengharapkan outcome yang bersifat spiritualitas, dan moralitas sementara kurikulum hanya difokuskan kepada kapasitas. Ketidaksinkronan inilah yang dijawab Kerangka Konseptual PAK 1.0 yang ditawarkan. Gambar 1.3 memperlihatkan diagram yang dimaksud.

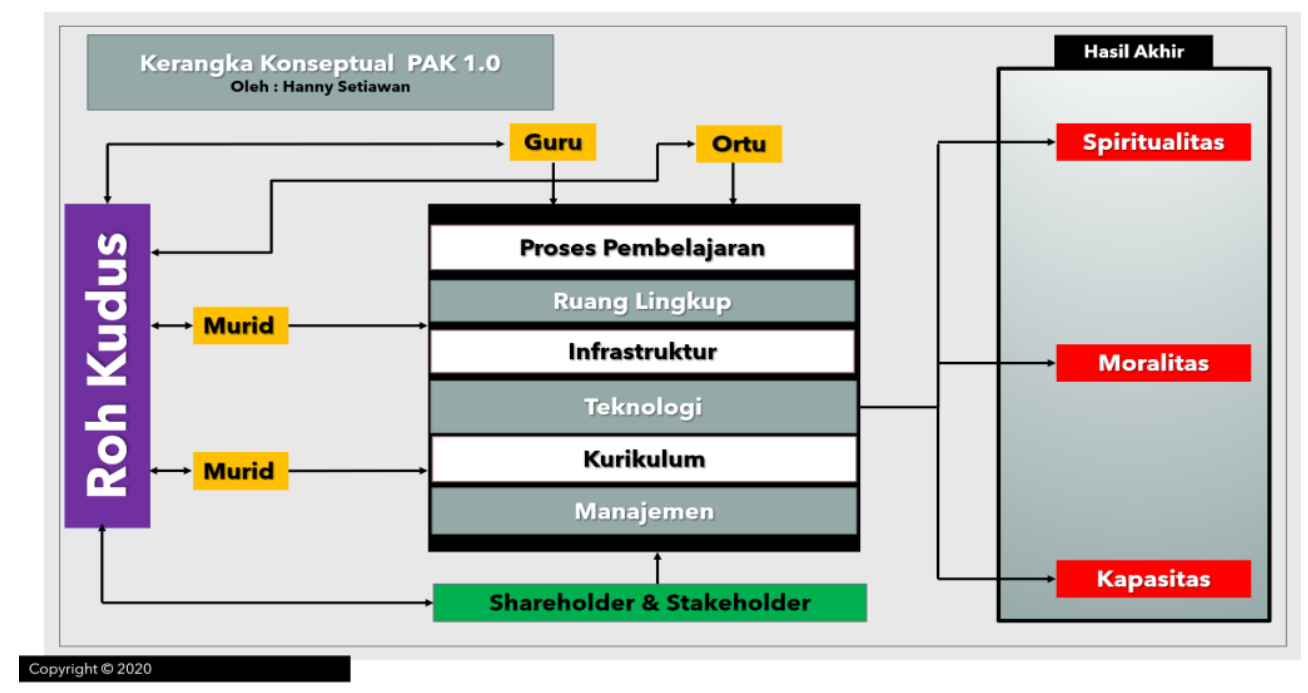

Gambar 3. (Pertentangan konseptual)

Kerangka Konseptual yang ditawarkan memperlihatkan bahwa Roh Kudus adalah unsur utama yang mempengaruhi bukan hanya guru dan murid, tapi juga stakeholder (pemangku kepentingan) serta shareholder (kepemilikan) dari PAK itu. Proses Pembelajaran (learning process), ruang lingkup (gereja, sekolah, keluarga), infrastruktur (sarana dan prasarana pembelajaran), teknologi yang siap untuk pembelajaran abad ke-21, kurikulum, dan manajemen adalah komponen-komponen yang bisa mendukung, tetapi bukan yang terutama. Roh Kudus bekerja melalui orangorang, Dia indwell (berdiam) pada orang bukan sistem. Hasil akhir, seperti yang 
menjadi inti penelitian dan pembahasan artikel ini, harus berakhir kepada spiritualitas, moralitas, dan kapasitas. Sebab aktualisasi terhadap spiritual, moralitas bahkan kapasitas seseorang dalam menjalankan setiap pekerjaan yang mengarah kepada pembelajaran seseorang.

Kerangka konseptual yang ditawarkan ini adalah dasar, dan bersifat sangat umum, perlu dikembangkan penelitian-penelitian lanjutan bagaimana mengonstruksi setiap unsur dan komponen pembelajaran, dan bagaimana menyatukan semua dalam satu kurikulum yang tertulis (written curriculum) dalam sekolah-sekolah umum, dan gereja pada khususnya.

\section{KESIMPULAN}

Hubungan antara supranatural dan natural berakar kepada sifat dualitas dari Yesus Kristus sebagai pusat Iman Kristen. Kolose 1:18 mengatakan, "Ialah kepala tubuh, yaitu jemaat. Ialah yang sulung, yang pertama bangkit dari antara orang mati, sehingga Ia yang lebih utama dalam segala sesuatu" Dalam pribadi Yesus seluruh rahasia Allah itu terungkap (Kol. 2:2). Sebab itu, prinsip indwelling dari pribadi Roh Kudus dalam diri guru murid adalah kunci untuk keberhasilan proses pembelajaran baik secara formal, non formal, atau informal dalam PAK.

Roh Kudus dalam diri guru-murid akan menuntun, menolong, memimpin kita menuju kedewasaan spiritualitas, moralitas, dan kapasitas sesuai dengan karunia dan talenta yang ada sejak dari kandungan (Mzm. 139). Interaksi antara guru-murid dan Roh Kudus melahirkan metakognisi spiritual yang akhirnya menjadi kunci kedewasaan rohani.

Pada mulanya adalah Allah (Kej. 1:1) yang menciptakan langit (supranatural) dan bumi (natural). Baik supranatural dan natural ada dalam satu realitas yang sama, yaitu realitas Tuhan. Kebenaran ontologis yang Alkitabiah ini ditujukan dalam pembahasan yang saling mengisi antara pneumatologi, metakognisi, dan PAK. Kerangka Konseptual yang dikonstruksi artikel ini bukan akhir, tapi sebuah awal usaha untuk menyatukan dua kutub rasionalisme dan mistisisme khususnya dibidang PAK. Penelitian-penelitian lebih lanjut masih diperlukan untuk melanjutkan pekerjaan besar ini. Paling tidak, "versi pertama" kerangka konseptual PAK yang 
seimbang antara iman dan logika sudah di-release, sehingga bisa menjadi landasan untuk penelitian, diskusi, dan pembahasan lebih lanjut.

\section{Endnotes:}

1 Hardi Budiyana, "Roh Kudus dalam Proses Pembelajaran Pendidikan Kristen Mewujudkan Pengajaran Kristen yang Mengandung Nilai Kekal," Jurnal Teologi Berita Hidup 1, no. 1 (2018), 57-77 https://doi.org/10.38189/jtbh.v1i1.5.

${ }^{2}$ Imanuel Adhitya Wulanata, "Peran dan Karya Roh Kudus Serta Implikasinya terhadap Pengembangan Pribadi dan Kualitas Pengajaran Guru Kristen [Roles and Work of the Holy Spirit and the Implications for the Personal Development and Teaching Quality of Christian Teachers]," Polyglot: Jurnal Ilmiah, 2018, https://doi.org/10.19166/pji.v14i1.326.

${ }^{3}$ Wulanata.

${ }^{4}$ Milliard J. Erickson, Christian Theology (Grand Rapids, MI: Baker Book House, 2002), 862.

5 Gidion Gidion, "Karya Roh Kudus dalam Meningkatkan Kualitas Sumber Daya Manusia (Sdm)," Shift Key: Jurnal Teologi dan Pelayanan 7, no. 1 (2017), 96-109 https://doi.org/10.37465/shiftkey.v7i1.9.

${ }^{6}$ Hardi Budiyana, Dasar-Dasar Pendidikan Agama Kristen, Cetakan ke berapa? (Surakarta: STT Berita Hidup, 2017). 35.

${ }^{7}$ S. A Nugraha, "Konsep Dasar Pendidikan Karakter," AL-MUNAWWARAH : Jurnal Pendidikan Islam, 2016.

${ }^{8}$ Kasih Haryo Basuki, "Pengaruh Kecerdasan Spiritual dan Motivasi,” Jurnal Formatif, 5, no. 2 (2015) 120-133.

${ }^{9}$ Basuki.

${ }^{10}$ Fredi Purwanto dan Rini Wulandari, "Implementasi Kecerdasan Spiritual Bagi Pendidikan," Missio Ecclesiae 9, no. 1 (2020): 95-112.

${ }^{11}$ BibleWorks ceased operation as a provider of Bibleworks, "BibleWorks," 2018.

12 Dickson. Adom and Adu..Agyem. Hussain, Emad.Kamil. and Joe, "Theoretical and Conceptual Framework : Mandatory Ingredients Theoretical and Conceptual Framework : Mandatory Ingredients," International Journal of Scientific Research 7, no. 1 (2018): 93-98, https://www.researchgate.net/publication/322204158\%0ATHEORETICAL.

${ }^{13}$ Fu'ad Arif Noor, "Metakognisi Dalam Pembelajaran RA," Aṣ-Ṣibyān: Jurnal Pendidikan Anak Usia Dini, 1, no. 1 (2016). 11-20

${ }^{14}$ Hardi Budiayana, Pendidikan Orang Dewasa - Suatu Tinjauan Pendidikan Kristen Orang Dewasa Dari Sudut Pandang Alkitab, Psikologi, dan Strategi Pengajaran, Ke-1 (Surakarta: STT Berita Hidup, 2018). 39.

${ }^{15}$ Hengki Wijaya, Strategi Menulis Jurnal Untuk Ilmu Teologi, ed. Sonny Eli Zaluchu (Semarang: Golden Gate Publishing, 2020), 25.

16 Amir Hamzah, Metode Penelitian Kepustakaan Library Research - Kajian Filosofis, Aplikasi, Proses, dan Hasil Penelitan, Revisi (Malang: Literasi Nusantara, 2020), 9.

${ }^{17}$ Bibleworks, "BibleWorks."

${ }^{18}$ Bibleworks.

${ }^{19}$ Jonathan Sheet, The River Runs (Singapore: Armour Publishing, 2019), 47.

20 Dio A. Pradipta, "Peristiwa Pentakosta Dipandang Dari Perspektif Teologi yang Transformatif," Matheo: Jurnal Teologi/Kependetaan $10, \quad$ no. $1 \quad$ (2020): $12-22$, https://doi.org/10.47562/matheo.v10i1.98.

${ }^{21}$ Harls Evan R. Siahaan, "Refleksi Konsep Proto Logos Lukas dalam Membangun dan Meningkatkan Kegiatan Publikasi Ilmiah di Lingkungan Sekolah Tinggi Teologi," BIA': Jurnal Teologi dan Pendidikan Kristen Kontekstual, 1, no. 2 (2018), 138-152. https://doi.org/10.34307/b.v1i2.61.

${ }^{22}$ Randy Frank Rouw, “Tugas Roh Kudus Dalam Misi Berdasarkan Kitab Kisah Para Rasul,” Jurnal Ilmiah Religiosity Entity Humanity (JIREH), 2019, 99-109. https://doi.org/10.37364/jireh.v1i1.7. 
${ }^{23}$ Heryanto David Lie, "Penggenapan Progresif Misi Allah Dalam Kisah Para Rasul 1:8," Jurnal Jaffray, 15, no. 5, (2017),63-69. https://doi.org/10.25278/jj71.v15i1.235.

24 Hardi Budiyana, Dasar-Dasar Pendidikan Agama Kristen, Ke-2 (Surakarta: STT Berita Hidup, 2017), 234.

${ }^{25}$ Robert W. Pazmino, Fondasi Pendidikan Kristen - Sebuah Pengantar Dalam Perspektif Injili, ed. Redaksi BPK Gunung Mulia, Ke-3 (Bandung: STT Bandung, 2016), 91.

${ }^{26}$ Pazmino, Fondasi Pendidikan Kristen - Sebuah Pengantar dalam Perspektif Injili, ed. Redaksi BPK Gunung Mulia, Ke-3 (Bandung: STT Bandung, 2016), 91.

${ }^{27}$ Purwanto and Wulandari, "Implementasi Kecerdasan Spiritual Bagi Pendidikan. Missio Ecclesiae 9, no. 1 (2020): 95-112."

${ }^{28}$ David K. Naugle, Wawasan Dunia Sejarah: Sebuah Konsep (Surabaya: Penerbit Momentum, 2010), 6.

${ }^{29}$ Khoe Yao Tung, Filsafat Pendidikan Kristen - Meletakkan Fondasi Dan Filosofi Pendidikan Kristen Di Tengah Tantangan Filsafat Dunia (Yogjakarta: Penerbit Andi, 2013), 8.

${ }^{30}$ Budiyana, Dasar-Dasar Pendidikan Agama Kristen, 60.

${ }^{31}$ Simon Chan, Spiritual Theology (Yogjakarta: Andi Offset, 2002), 13.

${ }^{32}$ Budiyana, Dasar-Dasar Pendidikan Agama Kristen, 336.

33 Adom and Hussain, Emad.Kamil. and Joe, "Theoretical and Conceptual Framework: Mandatory Ingredients Theoretical and Conceptual Framework : Mandatory Ingredients.”

${ }^{34}$ Adom and Hussain, Emad.Kamil. and Joe.

${ }^{35}$ David R Krathwohl, "A Revision of Bloom's Taxonomy: An Overview," Theory into Practice 41, no. 4 (2002): 212-19, https://doi.org/10.1207/s15430421tip4104.

${ }^{36}$ Ibid, 3.

${ }^{37}$ Putu Sabda Jayendra, "Konstruksi Level Pengetahuan Metakognitif Dalam Pembelajaran Agama Hindu," Guna Widya: Jurnal Pendidikan Hindu 5, no. 2 (2018), 37-45. https://doi.org/10.25078/gw.v5i2.638.

38 Moh. Zainal Fanani, "Strategi Pengembangan Soal Higher Order Thinking Skill (HOTS) Dalam Kurikulum 2013," Edudena: Journal of Islamic Religious Education 2, no. 1 (2018): 57-76.

${ }^{39}$ Robert J. Marzano dan John S Kendall, Designing dan Assessing Educational Objectives: Applying the New Taxonomy, Designing and Assessing Educational Objectives, 2008, 16.

${ }^{40}$ Endang Indarini, Tri Sadono, and Maria Evangeli Onate, "Pengetahuan Metakognitif Untuk Pendidik dan Peserta Didik," Satya Widya 29, no. 1 (2013): 40, https://doi.org/10.24246/j.sw.2013.v29.i1.p4046.

${ }^{41}$ Budiyana, Dasar-Dasar Pendidikan Agama Kristen, 45.

${ }^{42}$ Cepi Riyana, "Komponen-Komponen Pembelajaran," Komponen-Komponen Pembelajaran, 2011, 2.

${ }^{43}$ Nurul Huda, "Manajemen Pengembangan Kurikulum," Al-Tanzim : Jurnal Manajemen Pendidikan Islam 1, no. 2 (2017): 52-75, https://doi.org/10.33650/al-tanzim.v1i2.113.

\section{DAFTAR PUSTAKA}

Adom, Dickson., and Adu..Agyem. Hussain, Emad.Kamil. and Joe. "Theoretical and Conceptual Framework: Mandatory Ingredients Theoretical and Conceptual Framework: Mandatory Ingredients.” International Journal of Scientific $\begin{array}{lllll}\text { Research } & 7, & \text { no. } & 1 & \text { (2018): }\end{array}$ https://www.researchgate.net/publication/322204158\%0ATHEORETICAL. 
Basuki, Kasih Haryo. "Pengaruh Kecerdasan Spiritual Dan Motivasi." Jurnal Formatif, 2015.

Bibleworks, BibleWorks ceased operation as a provider of. "BibleWorks," 2018.

Budiayana, Hardi. Pendidikan Orang Dewasa - Suatu Tinjauan Pendidikan Kristen Orang Dewasa Dari Sudut Pandang Alkitab, Psikologi, Dan Strategi Pengajaran. Ke-1. Surakarta: STT Berita Hidup, 2018.

Budiyana, Hardi. Dasar-Dasar Pendidikan Agama Kristen. Cetakan ke. Surakarta: STT Berita Hidup, 2017.

—. "Roh Kudus Dalam Proses Pembelajaran Pendidikankristen Mewujudkan Pengajaran Kristen Yang Mengandung Nilai Kekal.” Jurnal Teologi Berita Hidup 1, no. 1 (2018): 57-77. https://doi.org/10.38189/jtbh.v1i1.5.

Chan, Simon. Spiritual Theology. Yogjakarta: Andi Offset, 2002.

Erickson, Milliard J. Christian Theology. Grand Rapids, MI: Baker Book House, 2002.

Fanani, Moh. Zainal. "Strategi Pengembangan Soal Higher Order Thinking Skill (HOTS) Dalam Kurikulum 2013.” Edudena: Journal of Islamic Religious Education 2, no. 1 (2018): 57-76.

Gidion, Gidion. "Karya Roh Kudus Dalam Meningkatkan Kualitas Sumber Daya Manusia (Sdm)." Shift Key: Jurnal Teologi Dan Pelayanan 7, no. 1 (2017). https://doi.org/10.37465/shiftkey.v7i1.9.

Hamzah, Amir. Metode Penelitian Kepustakaan Library Research - Kajian Filosofis, Aplikasi, Proses, Dan Hasil Penelitan. Revisi. Malang: Literasi Nusantara, 2020.

Huda, Nurul. "Manajemen Pengembangan Kurikulum.” Al-Tanzim: Jurnal Manajemen Pendidikan Islam 1, no. 2 (2017): 52-75. https://doi.org/10.33650/al-tanzim.v1i2.113.

Indarini, Endang, Tri Sadono, and Maria Evangeli Onate. "Pengetahuan Metakognitif Untuk Pendidik Dan Peserta Didik." Satya Widya 29, no. 1 (2013): 40. https://doi.org/10.24246/j.sw.2013.v29.i1.p40-46.

Jayendra, Putu Sabda. "Konstruksi Level Pengetahuan Metakognitif Dalam Pembelajaran Agama Hindu." Guna Widya: Jurnal Pendidikan Hindu 5, no. 
2 (2018). https://doi.org/10.25078/gw.v5i2.638.

Krathwohl, David R. “A Revision of Bloom's Taxonomy: An Overview.” Theory into $\begin{array}{llllll}\text { Practice } & 41, & \text { no. } & 4 & \text { (2002): }\end{array}$ https://doi.org/10.1207/s15430421tip4104.

Lie, Heryanto David. "Penggenapan Progresif Misi Allah Dalam Kisah Para Rasul 1:8.” Jurnal Jaffray, 2017. https://doi.org/10.25278/jj71.v15i1.235.

Marzano, Robert J, and John S Kendall. Designing \& Assessing Educational Objectives: Applying the New Taxonomy. Designing and Assessing Educational Objectives, 2008.

Naugle, David K. Wawasan Dunia Sejarah Sebuah Konsep. Surabaya: Penerbit Momentum, 2010.

Noor, Fu`ad Arif. "Metakognisi Dalam Pembelajaran RA." Aṣ-Ṣibyān: Jurnal Pendidikan Anak Usia Dini, 2016.

Nugraha, S. A. "Konsep Dasar Pendidikan Karakter.” AL-MUNAWWARAH : Jurnal Pendidikan Islam, 2016.

Pazmino, Robert W. Fondasi Pendidikan Kristen - Sebuah Pengantar Dalam Perspektif Injili. Edited by Redaksi BPK Gunung Mulia. Ke-3. Bandung: STT Bandung, 2016.

Pradipta, Dio A. "Peristiwa Pentakosta Dipandang Dari Perspektif Teologi Yang Transformatif." Matheo : Jurnal Teologi/Kependetaan 10, no. 1 (2020): 12 22. https://doi.org/10.47562/matheo.v10i1.98.

Purwanto, Fredi, and Rini Wulandari. "Implementasi Kecerdasan Spiritual Bagi Pendidikan." Missio Ecclesiae 9, no. 1 (2020): 95-112.

Riyana, Cepi. “Komponen-Komponen Pembelajaran.” Komponen-Komponen Pembelajaran, 2011, 1-63.

Rouw, Randy Frank. “Tugas Roh Kudus Dalam Misi Berdasarkan Kitab Kisah Para Rasul.” Jurnal Ilmiah Religiosity Entity Humanity (JIREH) 1, no. 1 (2019): 99-109. https://doi.org/10.37364/jireh.v1i1.7.

Sheet, Jonathan. The River Runs. Singapore: Armour Publishing, 2019.

Siahaan, Harls Evan R. "Refleksi Konsep Proto Logos Lukas Dalam Membangun Dan Meningkatkan Kegiatan Publikasi Ilmiah Di Lingkungan Sekolah Tinggi 
Teologi.” BIA': Jurnal Teologi Dan Pendidikan Kristen Kontekstual 1, no. 2 (2018): 138-52. https://doi.org/10.34307/b.v1i2.61.

Wijaya, Hengki. Strategi Menulis Jurnal Untuk Ilmu Teologi. Edited by Sonny Eli Zaluchu. Semarang: Golden Gate Publishing, 2020.

Wulanata, Imanuel Adhitya. "Peran Dan Karya Roh Kudus Serta Implikasinya Terhadap Pengembangan Pribadi Dan Kualitas Pengajaran Guru Kristen [Roles and Work of the Holy Spirit and the Implications for the Personal Development and Teaching Quality of Christian Teachers]." Polyglot: Jurnal Ilmiah, 2018. https://doi.org/10.19166/pji.v14i1.326.

Yao Tung, Khoe. Filsafat Pendidikan Kristen - Meletakkan Fondasi Dan Filosofi Pendidikan Kristen Di Tengah Tantangan Filsafat Dunia. Yogjakarta: Penerbit Andi, 2013. 